\title{
Multi-scale analysis of habitat association in a guild of blennioid fishes
}

\author{
Craig Syms* \\ University of Auckland Marine Laboratory, PO Box 349, Warkworth, New Zealand
}

\begin{abstract}
The degree to which reef fish are associated with particular reef characteristics has been the subject of much debate. It is increasingly clear that the strength of the relationship between reef fish and their habitat may be dependent on the scales at which the reef habitat is categorised. Consequently, scale must be explicitly incorporated into any investigation of fish and habitat association. I addressed the problem of scale by examining changes in the composition of a guild of blennioid fishes (comprising 13 species in the families Tripterygiidae and Blenniidae) relative to the scale at which their habitat was defined. Correspondence Analysis was used to display differences in guild structure. At large, geographical scales, characteristic blennioid assemblages could be detected. Changes in guild structure were due partly to differences in numerical dominance of a set of generalist species and, to a lesser extent, species composition. At broad scales, the blennioid assemblage displayed speciesspecific depth patterns and association with macroalgal cover. A core group of species was found at all depths, while others were restricted in depth and biogenic habitat type. The degree of shelter provided by topographic features characterised the blennioid assemblage at fine scales, and habitat specialisation became apparent at this scale. The patterns detected in this survey indicate scales at which questions about processes generating these patterns may be profitably addressed. I conclude that the incorporation of more than 1 scale in ecological studies is useful for reducing ambiguity and for generating a future research program of hypotheses.
\end{abstract}

KEY WORDS: Blennioids · Correspondence Analysis · Habitat association - Reef fish $\cdot$ Scale

\section{INTRODUCTION}

The distribution of organisms relative to their habitat is of central importance to ecology (Bell et al. 1990). The nature of this distribution provides an initial insight into the types of ecological processes that regulate populations and structure assemblages. In reef fish ecology, the relationship between the composition of demersal reef fish assemblages and the physical variables that characterise the reef has received considerable attention (Alevizon et al. 1985, Choat \& Ayling 1987. Holbrook et al. 1990b). The nature of this relationship is dependent on the scale at which it is examined (Addicott et al. 1987, Wiens 1989, Kotliar \& Wiens 1990). At some scales, associations between fish

\footnotetext{
- Present address: Department of Marine Biology, James Cook University, Townsville, Queensland 4811, Australia.

E-mail: craig.syms@jcu.edu.au
}

assemblages and certain habitat characteristics may be clearly defined, while at others relationships may be confused or non-existent (e.g. Roberts \& Ormond 1987). Incommensurability between scales of pattern and those of process may be responsible for disagreements between different researchers about the relative importance of processes structuring ecological communities. The scale at which patterns are measured may suggest appropriate scales at which to test hypotheses about mechanisms. In practice, reconciling processes and resultant patterns operating on different scales provides a major challenge to ecologists.

Large-scale patterns of fish distribution provide information on the regional or geographic structure of fish assemblages and have often been attributed to processes operating on similar scales. Oceanographic processes may influence fish assemblages by limiting the availability of fish larvae to an area (e.g. Choat et al. 1988). Large-scale geological factors may regulate 
fish assemblages by their influence on habitat structure patterns (e.g. Ebeling et al. 1980a, b). Biogeographical species pool size may determine the types of fish assemblages possible at a site (e.g. Gladfelter et al. 1980). In contrast, the large-scale distribution of chaetodontid fish along a $50 \mathrm{~km}$ transect across the Great Barrier Reef has been interpreted as 'niche replacement' based on local competitive processes (Anderson et al, 1981).

At a finer spatial scale $(<1 \mathrm{~km})$ studies have focused on the relationship between fish and 'broad'-scale (10s to 100 s of metres), often biogenic, habitat types and zones. Fish assemblages may be associated with physical habitat structure at this scale (e.g. Roberts \& Ormond 1987, Greenfield \& Johnson 1990a). Changes in fish composition may accompany changes in biogenic habitat structure (e.g. corals, Alevizon et al. 1985; macroalgae, Jones 1984. Choat \& Ayling 1987) and ontogenetic habitat changes (Jones 1984). Experimental manipulations are more practicable at this scale and have been used to identify some causal factors for these patterns. For example, broad-scale removal of macroalgae may affect local fish composition and abundance (Choat \& Ayling 1987, Bodkin 1988, Carr 1989, Holbrook et al. 1990a).

At even finer scales (centimetres to metres), physical habitat complexity, such as the ratio of volume to planar surface area or rugosity (Risk 1972, Luckhurst \& Luckhurst 1978aj, may also affect fish population structure. Early models of coral reef fish guilds drew attention to the fact that local assemblages may be influenced by competitive processes centred on local space availability (e.g. Sale 1977). Association of coral reef fishes with various habitat types has been recorded at this scale le.g. Gladfelter \& Gladfelter 1978, Luckhurst \& Luckhurst 1978b, Ogden \& Ebersole 1981, Roberts \& Ormond 1987, Gorham \& Alevizon 1989). The rugosity of the substratum may affect total fish abundance (Leum \& Choat 1980). Survivorship of fish cohorts may increase with increasing habitat complexity (Connell \& Jones 1991).

Marine studies that explicitly include more than 1 scale in their investigations of the relationship between fish and the physical structure of the reef are uncommon - despite multi-scale approaches being used by freshwater fish ecologists (e.g. Jackson \& Harvey 1989, Tonn et al. 1990) and recommended by marine fish ecologists (e.g. Jones 1988). Choat \& Ayling (1987) measured broad-scale habitat use by temperate reef fish on the coast of the North Island of New Zealand. In 2 studies, Greenfield \& Johnson $(1990 \mathrm{a}, \mathrm{b})$ recorded the association of blennioids and apogonids with broad-scale habitat variables over a regional extent from Belize to Honduras. Russ (1984) employed a hierarchical sampling regime to quantify spatial variability in distribution patterns of herbivorous fish across the Great Barrier Reef. Roberts \& Ormond (1987) considered the association between coral reef fish and habitat complexity over several scales. These studies demonstrated that incorporating more than 1 scale into an investigation was important in assessing the generality of the patterns and in deciding at which scales hypotheses about processes that generate the patterns could be addressed.

This study considers the effect of scale on the association of blennioid fishes with their habitat. In northern New Zealand the guild (sensu Root 1967) of small ( 3 to $14 \mathrm{~cm}$ ), demersal, diurnal, benthic carnivores on rocky reefs is composed largely of blennioids. Not all blennioids are considered part of the guild. For example, clinids spend most of their life amongst macroalgal fronds and so do not have the same substratum requirements. The blennioids of the guild are territorial fish which rest, feed, and lay eggs on the bottom. Within my study area the guild is composed of 13 species, of which 12 are triplefins (family Tripterygiidae) and 1 is a blenny (family Blenniidae). Nomenclature of this group, except where otherwise indicated, follows Paulin et al. (1989).

Blennioid fishes have received little attention in previous temperate studies, probably due to their oft cited cryptic behaviour and difficulty of identification. However, they are an amenable study group, being relatively unresponsive to the presence of a diver, site attached, and easy to count. Their small size and sedentary habits (Thompson 1983) enable a wide range of spatial scales to be incorporated into an ecological investigation. Temperate blennioids apear to have a long (up to $3 \mathrm{mo}$ ) larval life (Kingsford \& Choat 1989), so their distribution may be influenced by largescale oceanographic processes as well as smaller-scale competitive and other post-recruitment processes.

To measure how the structure of the guild of blennioid fishes changes with the scale of habitat classification, I sampled localities in the outer Hauraki Gulf in northeastern New Zealand and categorised each individual fish according to a 3-level habitat scale. Habitat classes are described in 'Methods' and ranged spatially from the large scale (i.e. 100 s of metres to $10 \mathrm{~s}$ of kilometres) to the broad scale (10s of metres) to the fine scale (centimetres to a metre).

\section{METHODS}

Sampling. This study was conducted in the outer Hauraki Gulf on the northeastern coast of New Zealand (Fig. 1). A total of 28 sites, separated by 100 s of metres to 100 kilometres, were sampled at haphazard times between mid-February and mid-December 1991. The 
austral summer months of mid-December to midFebruary correspond to peak recruitment of blennioids in the region; and, during this period, numerical dominance within the guild fluctuates due to species-specific recruitment timing differences (author's unpubl. data). After February, densities of all species decrease in approximately equal proportions so that the relative frequencies of species in a defined area are reasonably constant until the next recruitment season (author's unpubl. data). Consequently, I restricted sample times to this temporal 'window' between summer months.

The approach I took in this study was to let each individual fish define its own position in the habitat. In order to do this, I used an all-occurrence sampling procedure in which the position of each fish encountered was recorded according to 3 scales of habitat classification (large, broad, and fine). The large-scale habitat type was defined by position of the site within the outer Hauraki Gulf. Sites were separated by 100 s of metres to 10 s of kilometres and were characterised a priori by their geology and exposure to wave action. 'Exposed' sites were those most exposed to wave action from the predominant northeasterly/easterly swells. These sites generally had a greywacke-based substratum. Exposed sites could be subdivided into offshore islands and mainland shores. 'Semi-exposed' sites had a lesser degree of exposure to the east, and the substratum was commonly sandstone. These sites were found only on the mainland. 'Sheltered' sites were exposed to very little wave action, generally had a sandstone substratum, and were present on the mainland and in the lee of Great Barrier Island.

Broad-scale habitat types were defined by a combination of depth and biogenic structure (Table 1). The major biogenic feature on northeastern New Zealand reefs is macroalgae - primarily the laminarian Ecklonia radiata, the fucalean Carpophyllum species, and other assorted brown algae which form mixed beds (Choat \& Schiel 1982). Grazed rock flats were devoid of brown macroalgae and covered with coralline 'paint' or turf. Broad-scale habitat classes corresponded to a spatial scale of 10 s of metres. A combination of substratum type (e.g. rock, cobbles, sand) and aspect (e.g. under overhangs, in vertical cracks, on top of the substratum) formed the basis of the fine-scale classification (Table 2). Fine-scale habitat types corresponded to a spatial scale of centimetres to a metre.

Each site was sampled on SCUBA by a 75 min timed count. All-occurrence sampling was used in preference to a more rigorous, transect-based sampling for a variety of rea-

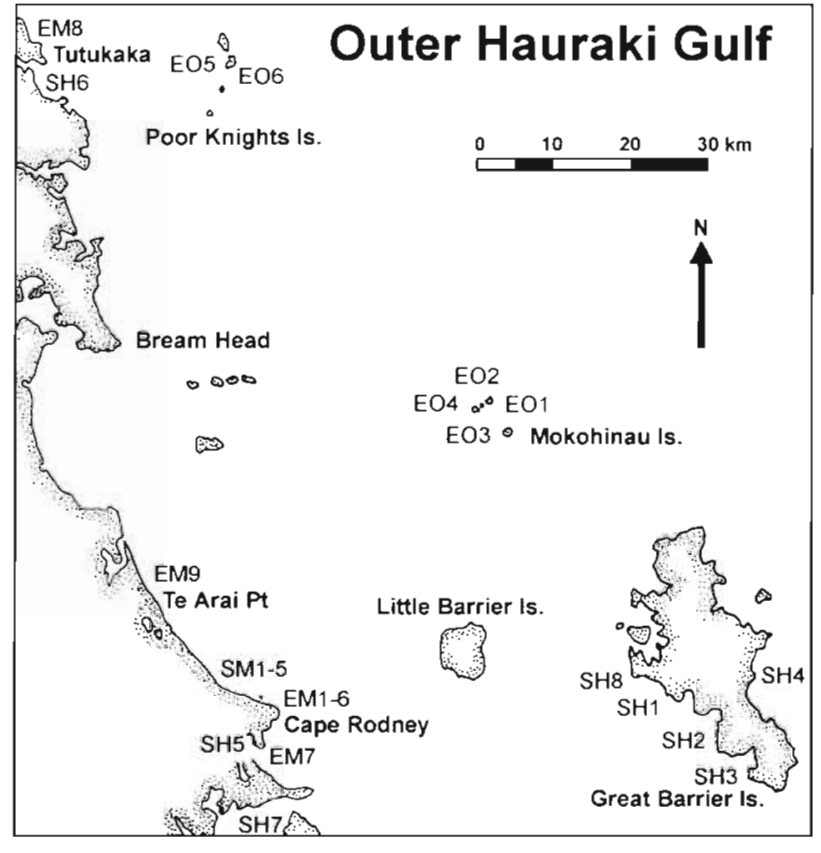

Fig. 1 Distribution of large-scale sample sites in the outer Hauraki Gulf, northeastern New Zealand. EO: exposed offshore; EM: exposed mainland; SM: semi-exposed mainland; SH: sheltered

Table 1. Broad-scale habitat classes

\begin{tabular}{|c|c|c|}
\hline Class & Frequency & Description (depth) \\
\hline SRG & 39 & Surge zone. Above the sublittoral fringe \\
\hline SMA & 873 & $\begin{array}{l}\text { Shallow mixed algae. Sublittoral brown, } \\
\text { red or green algae }(0 \text { to } 5 \mathrm{~m})\end{array}$ \\
\hline DMA & 363 & Deep mixed algal beds ( 5 to $10 \mathrm{~m}$ ) \\
\hline SRF & 1206 & $\begin{array}{l}\text { Shallow rock flat. Urchin grazed rock } \\
(0 \text { to } 5 \mathrm{~m})\end{array}$ \\
\hline MRF & 1770 & $\begin{array}{l}\text { Mid rock flat. Urchin grazed rock } \\
(5 \text { to } 10 \mathrm{~m})\end{array}$ \\
\hline SEA & 104 & $\begin{array}{l}\text { Shallow encrusting algae. Not grazed } \\
\text { by urchins. Usually on exposed } \\
\text { vertical rock faces }(0 \text { to } 5 \mathrm{~m})\end{array}$ \\
\hline EA & 103 & Encrusting algal faces ( 5 to $10 \mathrm{~m}$ ) \\
\hline SFX & 30 & $\begin{array}{l}\text { Shallow Carpophyllum flexuosum } \\
\text { forest }(0 \text { to } 5 \mathrm{~m})\end{array}$ \\
\hline FLX & 103 & Carpophyllum flexuosum forest ( 5 to $10 \mathrm{~m}$ ) \\
\hline SE & 857 & Shallow Ecklonia radiata forest (5 to $10 \mathrm{~m}$ ) \\
\hline EF & 2077 & Ecklonia radiata forest (10 to $15 \mathrm{~m})$ \\
\hline $\mathrm{DE}$ & 1056 & Ecklonia radiata forest ( 15 to $20 \mathrm{~m}$ ) \\
\hline DDE & 129 & Ecklonia radiata forest ( 20 to $30 \mathrm{~m}$ ) \\
\hline SG & 55 & $\begin{array}{l}\text { Sponge Garden. Sediment flats } \\
\text { with sponges dominant ( } 15 \text { to } 20 \mathrm{~m})\end{array}$ \\
\hline DR & 181 & $\begin{array}{l}\text { Deep reefs. Deep rock with } \\
\text { encrusting invertebrates and sparse } \\
\text { Ecklonia radiata }(15 \text { to } 20 \mathrm{~m})\end{array}$ \\
\hline DDR & 62 & Deep reefs $(20$ to $30 \mathrm{~m})$ \\
\hline
\end{tabular}


Table 2. Fine-scale habitat classes

\begin{tabular}{|lrl|}
\hline Class & Frequency & Description \\
\hline SR & 3651 & On the side of a rock face or bouider \\
TR & 2258 & On the top of a rock face or boulder \\
AJ & 816 & $\begin{array}{l}\text { Adjacent to or at the base of a } \\
\text { vertical rock face or boulder }\end{array}$ \\
VK & 608 & $\begin{array}{l}\text { In a crack on a vertical rock face or } \\
\text { boulder }\end{array}$ \\
BO & 390 & At the bottom of an overhang \\
TC & 362 & On the top of cobbles \\
UR & 306 & Appressed under an overhang \\
UC & 215 & Underneath cobbles \\
AN & 124 & Associated with massive sponges \\
FK & 98 & In a crack on horizontal rock faces \\
UN & 70 & Underneath sea urchins \\
SN & 57 & On sand $>1.5$ m from nearest rock \\
HL & 53 & Inside mollusc-bored holes in rock \\
\hline
\end{tabular}

sons. Pilot studies showed that line transects took more time to deploy to obtain fish frequencies similar to those obtained with all-occurrence samples _ an important limitation given the time restrictions imposed by the depth of many sites. In addition, uncommon species were often missed with line transects because less area could be sampled in a given time. Consequently, I modified the methods of Williams (1982) and Russ (1984) and recorded the absolute frequencies of all blennioids encountered during a timed count. The implications of this sampling method are discussed below. Due to within-year decreases in fish numbers, I analysed the relative frequencies of fish and did not attempt to standardise the counts to areal units (densities).

Within each site, I stratified counts by depth instead of habitat. This ensured that all habitats present at a site were sampled in proportion to their occurrence. Stratification by habitats or zones would have required some estimate of the proportion of each habitat type within each site to attain an unbiased fish-frequency distribution for that site. I divided the 75 min sampling time equally among depth strata of $5 \mathrm{~m}$ or, in water of less than $10 \mathrm{~m}$ depth, $2.5 \mathrm{~m}$. This was to ensure fish at all depths had equal probabilities of being encountered. Searches were conducted to a depth of $30 \mathrm{~m}$, beyond which bottom-time restrictions precluded effective sampling. At sites of less than $30 \mathrm{~m}$ depth, I searched down the reef until the rock substratum was replaced with sand. To count fish, I swam a slow, zigzag pattern within a depth stratum, searching $0.75 \mathrm{~m}$ to either side and in front of me. As the fish in the guild are small, generally drab in colour and pattern, and water visibility was often limited, the tendency to scan ahead and oversample conspicuous individuals was reduced. I recorded the species of each blennioid encountered, whether it was an adult or $0+$ recruit (based on the size and body shape of the fish), and the fish's place within the 3 levels of habitat classification (large, broad, and fine scale).

Analysis. The all-occurrence, depth-stratified sampling program used in this study was designed to let the fish define their own habitats. The sampling universe, therefore, is composed only of the habitats occupied by blennioids - not all habitats present at a site. This is because the absence of blennioids from a habitat type resulted in that habitat type not being recorded during all-occurrence sampling. Absolute abundance differences between habitats are not possible because habitats at a given site were sampled in proportion to their availability and not allocated equal sample effort. This was a necessary condition for an unbiased estimate of guild composition at each site (see below). Consequently the data should be interpreted as species differences within habitats, i.e. the composition, dominance, and relative abundance of species within each habitat type, and not habitat choices within a single species. However, gross differences in relative abundance (e.g. 2 orders of magnitude or greater) or presence and absence of species from particular habitats are reasonable evidence that some species will be found only in certain habitats

A major requirement for the analysis of speciesfrequency data is that the data be unbiased with respect to species. When this condition is fulfilled, then the frequency of a species within a habitat will be directly proportional to its density in that habitat, as the area sampled is constant for all species within a habitat. Bias in this study was avoided in 2 ways. At the largest scale, depth stratified counts enabled all habitats to be sampled in proportion to their availability. At the finer habitat scales, bias was avoided by searching a strip of limited width $(1.5 \mathrm{~m})$, for a pre-defined time, and not scanning ahead and possibly orienting toward conspicuous individuals.

As the sampling regime was not ordered in a factorial manner I compiled the data as 3 contingency (frequency) tables which were analysed independently of each other: (1) large scale $x$ species; (2) broad scale $x$ species; (3) fine scale $\times$ species.

These data were analysed by Correspondence Analysis (CA) using the CORRESP procedure in SAS (SAS Institute 1988) to graphically summarise the relative distances between different habitat categories (based on their species composition) and between different species (based on their relative habitat use). Interpretation of the CA was based on the plots of habitat class and species using the first 2 axes of the analysis. To indicate the adequacy of the ordination axes in de- 
scribing habitat class and species relationships, a circle with a diameter proportional in size to the profile inertia for the 'weight' each row in the frequency table contributes to the analysis) explained by the ordination axes is plotted in most cases. A large circle indicates the point is well represented in the ordination space. A more detailed discussion of CA may be found in Greenacre (1984). In addition, I applied different ordinations [Principal Component Analysis and Principal Co-Ordinate analyses of the Manhattan (compositional) distance and Jaccard's coefficient] to ascertain the robustness of the patterns to different ordination methods. Patterns identified by CA were, for the most part, identified also by the other methods. Outliers were identified by initial plots of the principal axes and the contributions of profiles (or rows of the contingency table) to the 'mass' of the axis (Greenacre 1984). Where appropriate, outliers were removed from the analysis.

Average linkage cluster analysis of row-total standardised frequencies (proportions) was used (PROC CLUSTER; SAS Institute 1987) when clusters (c.f. gradients) were suggested by the plot. Significance of cluster levels was judged against the mean cluster value of the analysis. Where habitat categories formed clusters, I present the ordination of the habitat and the frequency distribution of species in each cluster. Where species distribution followed gradients, I present the ordinations of habitat types and of species.

For the large-scale analysis I used only the frequencies of adults, as sites were sampled haphazardly throughout the year and recruits would, consequently, be unevenly represented across sites. For the broadand fine-scale analyses, I ran each analysis both with and without recruits. If the resulting ordination demonstrated no difference between adults and recruits of each species, I combined the values and reran the analysis.

Levels of habitat classification are unlikely to be independent of one another, e.g. fine-scale topography may be dependent on large-scale geology. This dependence could not be statistically factored out. Consequently, to quantify the inter-dependence of habitat types, I ran a Multiple Correspondence Analysis (MCA) on the combined species frequencies of all fish in each habitat scale (SAS Institute 1988). This enabled a diagrammatic assessment of the degree to which habitat types are correlated.

\section{RESULTS}

\section{Large scale}

A total of 28 sites in the outer Hauraki Gulf were sampled (Fig. 1) and 6962 adult fishes from 13 species

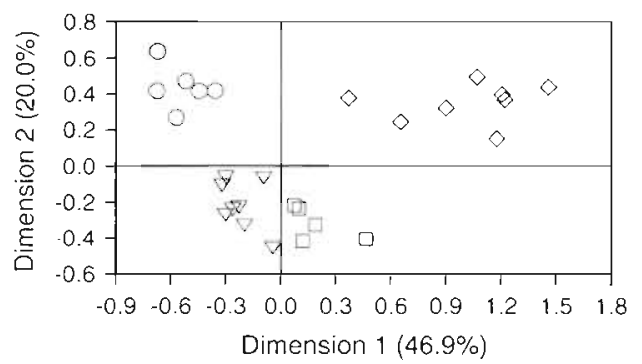

Fig. 2. Large-scale blennioid assemblages recognised by Correspondence Analysis. The multivariate outlier, Te Arai Point (EM9; see Fig. 1), was not included in the analysis and is consequently not presented on the plot. (O) Exposed offshore; $(\nabla)$ exposed mainland; $(\square)$ semi-exposed mainland; $(\diamond)$ sheltered. Proportion of inertia (or 'quality') of each site explained by the 2 axes ranges from 0.41 to 0.93

recorded. A combination of ordination and clustering methods identified 4, possibly 5, assemblages along an exposure gradient (Fig. 2). The exposed, outer offshore islands were characterised by numerical dominance of Notoclinops segmentatus, with significant contributions from $N$. caerulepunctus (described by Hardy 1989a), Karalepis stewarti, N. yaldwyni, and the yellow/black (presently undescribed; see Paulin et al. 1989) triplefin (Fig. 3)

The exposed greywacke-based mainland assemblages were also dominated numerically by Notoclinops segmentatus. However, an increase in the frequency of Forsterygion varium, Ruanoho whero, and Parablennius laticlavius, combined with reduced frequencies of Karalepis stewarti, N. yaldwyni, and the yellow/black triplefin distinguished these assemblages from the exposed offshore sites. The blue-dot triplefin $N$. caerulepunctus was absent from the mainland south of Tutukaka.

Semi-exposed mainland sites with eroded sandstone platform reefs were very similar to exposed greywacke sites in faunal composition, but numerical dominance was shared by Notoclinops segmentatus and Forsterygion varium. Ruanoho whero formed a significant component of the guild and $F$. lapillum (described by Hardy 1989b) increased in relative abundance.

Sheltered sites on both the mainland and Great Barrier Island were numerically dominated by Forsterygion lapillum and Ruanoho whero. In contrast, Notoclinops segmentatus and Parablennius laticlavius occurred in smaller proportions at these sites. The other species that characterised the offshore islands, with the exception of the yellow/black triplefin, were practically absent. The fifth assemblage was represented at only 1 site, Te Arai Point (Site EM9), classed a priori as an exposed-mainland site. This assemblage was numerically co-dominated by $F$. varium and 'Tripterygion' robustum (the 'robust' triplefin, not 
included in Paulin et al. 1989, but provisionally referred to as 'Tripterygion' robustum Clarke; G. S. Hardy, New Zealand National Museum, pers. comm. 1989) - a species rarely recorded at any of the other sites. Te Arai was similar to the other exposed-mainland sites in all other faunal elements.

In summary, Notoclinops segmentatus, Ruanoho whero, Parablennius laticlavius, and Forsterygion varium were numerically important across all sites, but with different dominance patterns correlated with wave exposure. N. caerulepunctus, Karalepis stewarti, $N$. yald- wyni, and the yellow/black triplefin were all present on the mainland, but were relatively more abundant at the offshore islands. F. lapillum and $F$, varium were rare on offshore islands, but increased in importance with increasing shelter from wave exposure. $F$. varium was dominant in semi-exposed sites and $F$. lapillum in sheltered sites. Conversely, $N$. segmentatus was dominant in exposed areas and rarer in more sheltered waters. 'Tripterygion' robustum was unusual in its distribution, being found at only 1 site on the mainland

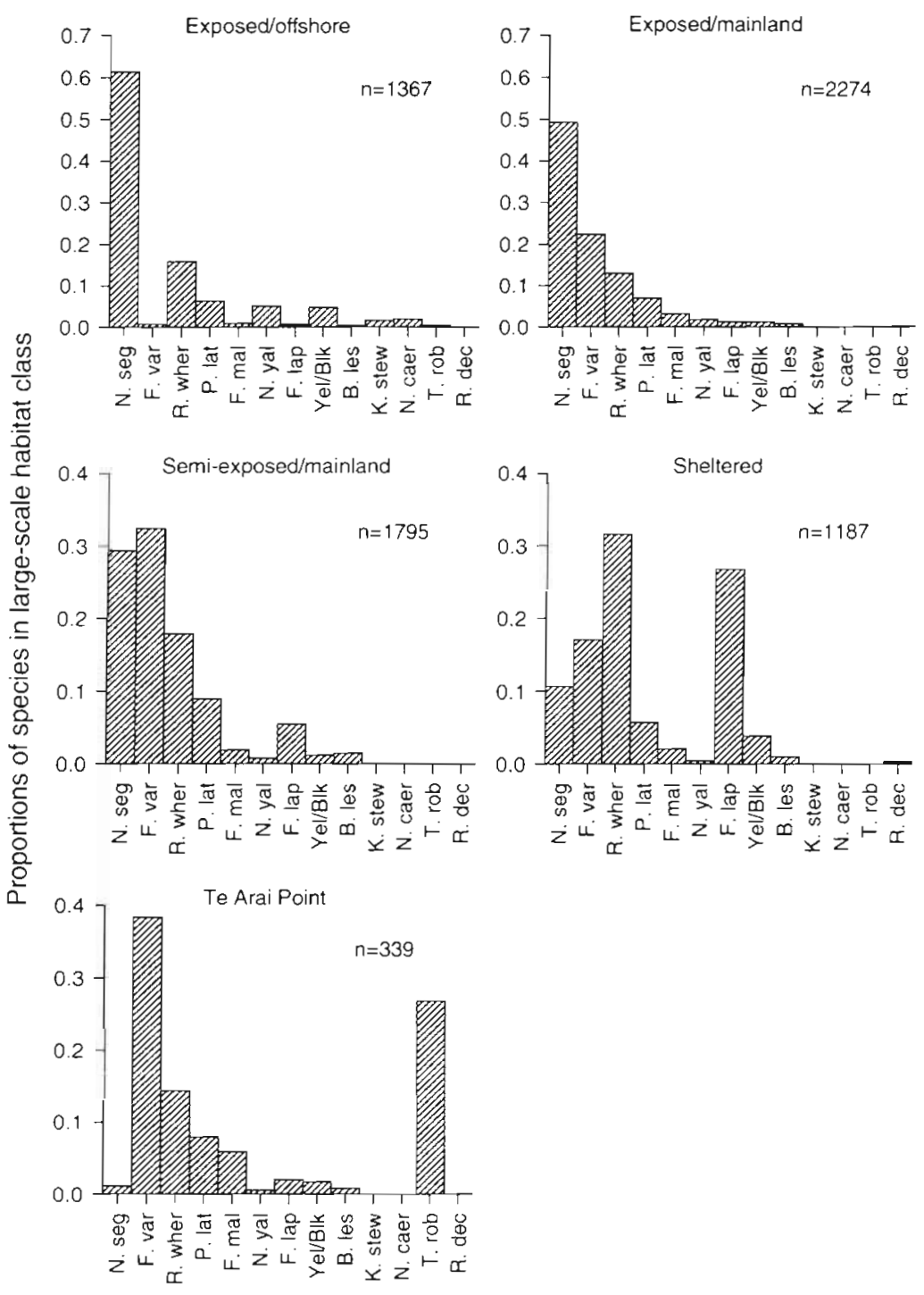

Fig. 3. Proportions of species occurring in large-scale clusters and the outlier, Te Arai Point. N. seg: Notoclinops segmentatus; F. var: Forsterygion varium; R. wher: Ruanoho whero; P. lat: Parablennius laticlavius; F. mal: Forsterygion malcolmi; N. yal: Notoclinops yaldwyni; F. lap: Forsterygionlapillum; Yel/Blk: yellow/black triplefin; B. les: Bellapıscis lesleyae; K. stew: Karalepis stewarti; N. caer: Notoclinops caerulepunctus; T rob: 'Tripterygion' robustum; R. dec: Ruanoho decemdigitatus

\section{Broad scale}

The broad-scale habitat classifications of 9008 adult and juvenile fish from 13 species were recorded. Guild structure varied strongly along a depth/macroalgal gradient (Fig. 4). Initial ordinations indicated there were no differences between adult and recruit distributions at this scale. Consequently, adults and recruits of each species were pooled. There was a 'core' of species found throughout the depth range - Notoclinops segmentatus, Ruanoho whero, and Forsterygion varium (Fig. 5) - as indicated by their proximity on the ordination to the centroid $(0,0$ on the axes). The guild in the deep reef/deep Ecklonia radiata habitats was characterised by a strong yellow/black triplefin and $F$. malcolmi component. Below $20 \mathrm{~m}, N$. caerulepunctus assumed greater importance. Middle depth ranges (5 to $20 \mathrm{~m}$ ) of E. radiata and mixed fucoid algae were very similar in fish species composition, with $N$. segmentatus, $F$, varium and $R$. whero as the main species. The shallow rock flats and shallow mixed algae were characterised by Parablennius laticlavius and $N$. yaldwyni (Fig. 5). On the mainiand, especially in sheitered sites, F. lapillum was also more dominant in these habitats. The shallow encrusting algae habitat was characterised by relatively more $N$. yaldwyni and P. laticlavius and occasional Bellapiscis lesleyae. The surge zone, an outlier not presented on the plot, was occupied almost entirely by $B$. lesleyae. The fish assemblage on grazed rock flats did not differ from that at mixed algal beds at the same depth. In contrast, grazed rock flat assemblages were distinguishable from E. radiata for- 


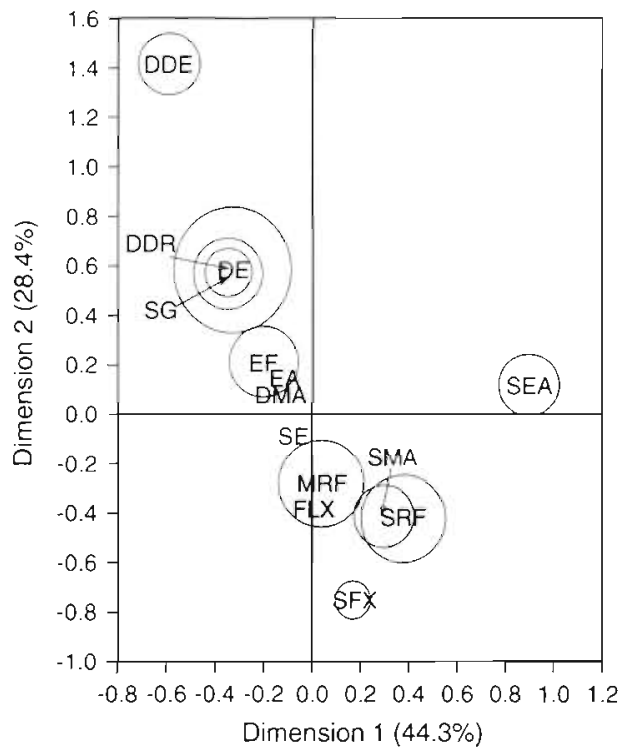

Fig. 4. Ordination of broad-scale habitat classes (see Table 1) by Correspondence Analysis. Not included is the 'surge' habitat which lies off the figure at $7.71,3.01$. Diameters of circles are proportional to the 'quality' of the reduced space

est assemblages at the same depth. This was due to increased proportions of $P$. laticlavius in grazed habitats. Carpophyllum flexuosum forests were dominated by $F$. lapillum, $R$. whero, and $F$, varium.

In summary, Notoclinops segmentatus, Ruanoho whero, and Forsterygion varium were widespread in their broad-scale habitat use. $N$. caerulepunctus, the yellow/black triplefin, and F. malcolmi were found primarily in deeper habitats regardless of biogenic structure. F. lapillum was usually found in shallow mixed algal habitats. N. yaldwyni was found in the shallow mixed algal zones and Parablennius laticlavius in the shallow rock flat to mixed algal zones. Bellapiscis lesleyae was found primarily in the surge zone and was the only occupant of that habitat.

\section{Fine scale}

The fine-scale habitat classifications of 9008 adult and juvenile fish from 13 species were recorded. There was considerable overlap among species in their fine-scale habitat use - most habitats were occupied by all species, but some habitats were occupied by only 1 or 2 species. Consequently patterns are more complex than at previously examined scales. Generally, fine-scale habitats fall in 2 classes along the first dimension of the ordination. Habitats with a positive value on the first axis provide more shelter (e.g. under cobbles, bottom of overhangs, in cracks, adjacent to large rocks) than those with a negative value on the axis (e.g. on the top and sides of

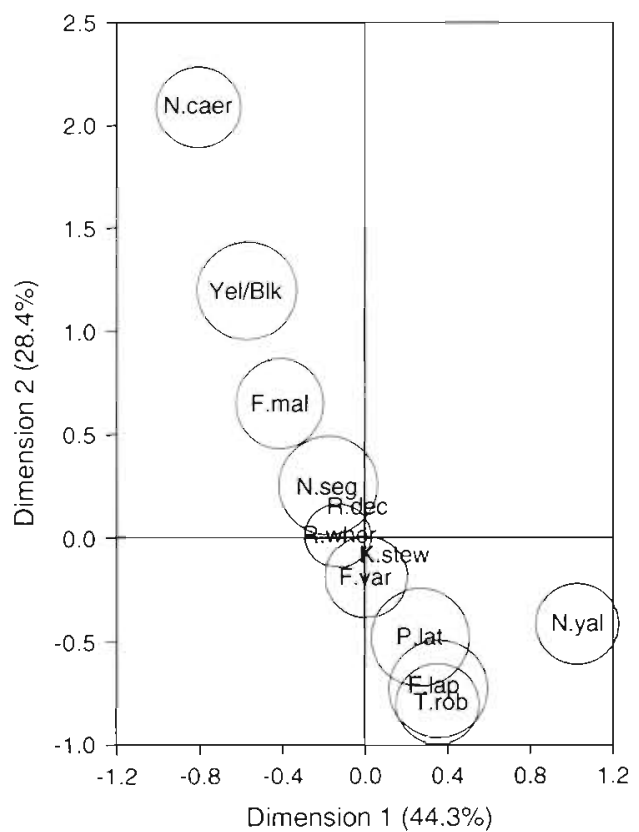

Fig. 5. Ordination of species in broad-scale habitat classes by Correspondence Analysis. See Fig. 3 for complete names of species. Diameters of circles are proportional to the 'quality' of the reduced space. Not included is Bellapiscis lesleyae which lies off the plot at 5.69, 2.02 and is associated predominantly with 'surge' habitats

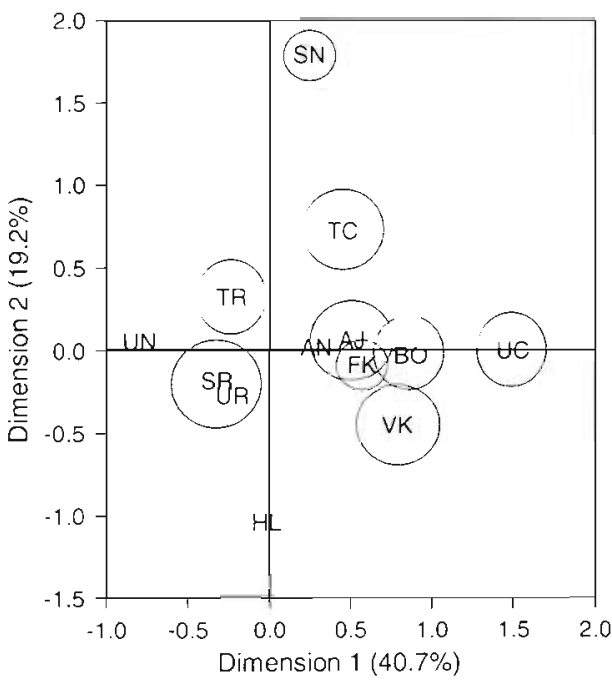

Fig. 6. Ordination of fine-scale habitat classes (see Table 2) by Correspondence Analysis. Diameters of circles are proportional to the 'quality' of the reduced space

rocks) (Fig. 6). An 'arching' of the habitats on the second axis indicates the 'sand' and 'top of cobbles' habitats are also distinct. Specialist habitats (i.e. habitats occupied by only 1 or 2 species), such as mollusc holes (HL), and under urchins (UN), are also apparent, though poorly represented on this plot (Fig. 6). 


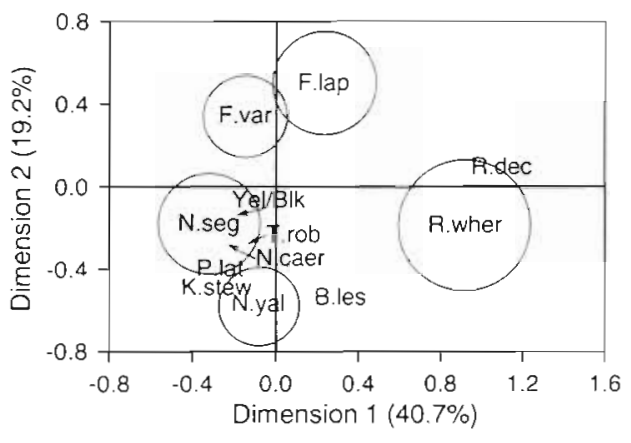

Fig. 7 Ordination of species in fine-scale habitat classes by Correspondence Analysis. See Fig 3 for complete names of species. Diameters of circles are proportional to the 'quality' of the reduced space

The plot of species in the reduced space helps to explain these patterns (Fig. 7). Sheltered habitats were commonly occupied by Ruanoho whero. The 'arching' on the second axis is due to the numerical dominance of Forsterygion lapillum in the 'sand', and 'top of cobbles' habitats. Out of the exposed habitats, $F$. varium is more likely to be found on the most exposed, i.e. on top of rocks. Most other species were found on the next most exposed habitat class, the sides of rocks. Of these species, only 2 appear to have a strong association with this habitat type - Notoclinops segmentatus and $N$. yaldwyni.

Two habitats are not well represented on this plot but were still important in lower dimensions (i.e. other ordination axes) of the analysis. Parablennius laticlavius and Notoclinops segmentatus recruits were the only species associated with sea urchins, where they often sheltered beneath the spines. Holes in the rock, bored by pholadid molluscs, were occupied solely by $P$. laticlavius.

In summary, there was generally a wide overlap in fine-scale habitat use. However, some species were found particularly in open or low-cover habitats (e.g. Forsterygion varium, Notoclinops segmentatus), and others were associated with a high degree of cover (e.g. Ruanoho whero). No species was restricted to only 1 type of habitat, but some types of habitat were used only by particular species.

\section{Interdependence of habitat types}

Different scales of habitat classification are likely to be dependent on each other. As this sampling program was not designed to orthogonally factor out this dependence, an ad hoc analysis was used to determine the degree to which this exerted an effect. Multiple Correspondence Analysis (MCA) of the 3-way frequency table of total fish numbers (i.e. independent of species information) was used to graphically display the habitat-category interdependence. Categories at a similar angle from the centroid configuration (i.e. 0,0 on the axes) are more closely associated with each other. The first 2 axes of the ordination represent differences between the degree of shelter at each site and account for $21.5 \%$ of the variation (Fig. 8).

Deep habitats (20 to $30 \mathrm{~m}$ ) and algal encrusted rock faces were associated with exposed offshore sites. Offshore sites such as the Poor Knights and Mokohinau Island groups are close to the continental shelf, and water depths may reach $100 \mathrm{~m}$ at the base of the reef. In contrast, deep rock habitats are not widely represented at mainland sites where the reef generally ends at between 10 and $20 \mathrm{~m}$. Encrusting algal faces are associated with sheer rock walls between 0 and $10 \mathrm{~m}$ on offshore islands and between 0 and $5 \mathrm{~m}$ on mainland sites exposed to wave action. Stands of the fucoid macroalga Carpophyllum flexuosum, sand patches, and cobbles were associated with sheltered sites. The prevalence of blennioids on sand in these habitats is most likely due to the shallow (usually between 7.5 and $10 \mathrm{~m}$ ) depth of these reefs, which led to the rock/sand interface being sampled more often. Mixed algal beds, holes, grazed rock flats and urchins were associated with semi-exposed sites. Exposedmainland sites were centroidal in their habitat composition - they represent the 'average' distribution of habitat types across the study.

Despite the association of most broad-scale habitats and the 'specialist' fine-scale habitat types with largescale classes, the degree of cover afforded by the fine-

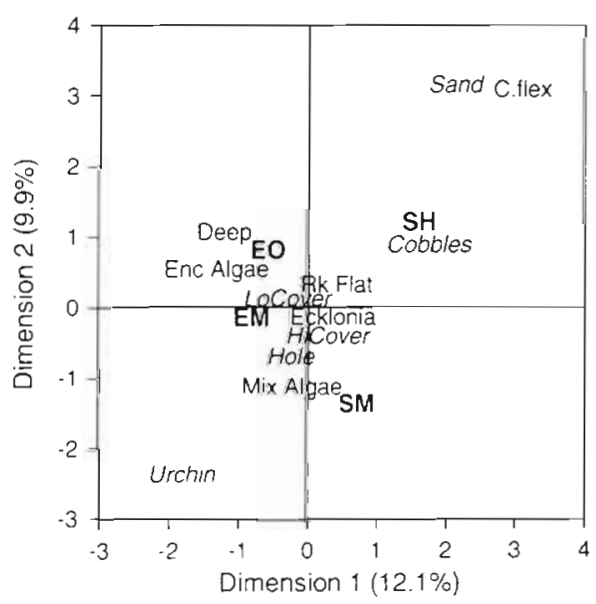

Fig. 8. Ordination of total occurrence (across species) of habitat classes by Multiple Correspondence Analysis. Large-scale classes (definitions as in Fig. 1.) are in bold font, broad-scale in plain font, fine-scale in italics. Enc Algae: encrusting algal faces; Rk Flat: grazed rock flats; Ecklonia: Ecklonia radiata forest; Mix Algae: mixed fucalean algae forest; Cflex: Carpophyllum flexuosum forest; LoCover: low-cover habitats; HiCover: high-cover habitats 
scale topography was centroidal, i.e. regardless of the large-and broad-scale habitat types, blennioids were found in similar degrees of shelter. The broad-scale Ecklonia radiata habitat class was also not strongly associated with any other particular habitat type.

\section{DISCUSSION}

The degree of association of organisms with their habitat is an important component of many ecological theories and concepts. Habitat space may in itself be limiting (Smith \& Tyler 1972, Sale 1975), as required by the 'lottery hypothesis' Populational responses to habitat change may imply resource limitation (Doherty \& Williams 1988a, b) or enhancement (Carr 1989, Schmitt \& Holbrook 1990a). Habitat patchiness may alter levels of competition (Schmitt \& Holbrook 1990b) and predation (Schmitt \& Holbrook 1985). Despite cautions from many researchers about the scales at which organism/habitat relationships are measured, few studies have explicitly incorporated different habitat scales into their analyses. In this study, I used a relatively simple scale alteration technique to consider different ways in which a fish assemblage could be perceived. The different scales at which patterns are measured may in turn suggest relevant hypotheses about the scales at which processes responsible for these patterns operate.

The largest scale considered in this study ranged from 100 s of metres to 100 kilometres of ocean from north to south. At this scale, blennioids can be seen as forming reasonably distinct groups according to degree of exposure and geological nature of the site. Groups differed in 2 ways. A core group of 4 species was found at all sites. Variation in the relative dominance of these species was responsible for among-site guild differences. In addition, some species were restricted to certain places.

In the outer Hauraki Gulf, large-scale oceanographic features such as the East Auckland Current have been suggested to influence fish assemblage composition by transporting subtropical fish larvae (notably wrasses and the damselfish Parma alboscapularis) down the northeastern coast of New Zealand (Ayling \& Grace 1971, Choat \& Ayling 1987, Choat et al. 1988). In this region, blennioids have a long larval life, up to 3 mo (Kingsford \& Choat 1989), and it is not unreasonable to speculate that transport of subtropical larvae may influence the assemblage structure. However, this hypothesis is not borne out by the data. The only blennioids of true tropical/subtropical affinity are the rare Plagiotremus tapeinosoma and the widespread Parablennius laticlavius. In addition, no subtropical triplefins such as Vauclusella rufopilea or blemnies such as Cirripectes alboapicalis and Entomacrodus spp., found on Norfolk Island (Francis et al. 1990) and the Kermadec Group, have been recorded from mainland New Zealand.

Smaller-scale (1 to 100 s of $\mathrm{km}$ ) linear oceanographic features (sensu Kingsford 1990) operating both across (east-west) the continental shelf and from north (proximal to the continental shelf) to south (inner gulf) may exert some influence on the guild. The relationship between the guild and water quality is not simple. Within the region there is a north to south gradient from clear, oceanic water to turbid, onshore water. This gradient is confounded with the increased distance of southern sites from the continental shelf. In addition, sites that are spatially very close to each other (e.g. SH6 and EM8, $300 \mathrm{~m}$ apart), yet lie at different positions within a harbour, may have very different sediment levels and fauna. Sediment loading has been suggested to influence fish assemblages in the Caribbean (Dennis \& Bright 1988) and the composition of fish at sites in the Hauraki Gulf (Kingsford 1989). Fish communities on the Great Barrier Reef (Williams 1982, Russ 1984) and Californian coast (Ebeling et al. 1980 a) have also been associated with water clarity. Whether this is a result of water quality itself or associated properties of water bodies such as larval retention in internal waves (Kingsford 1990) is worthy of attention, especially given the inconsistent relationship between spatial proximity and site characteristics.

It is likely that large-scale geological characteristics also influence guild composition. There are 2 mechanisms by which this may occur. First, geological formations may alter oceanographic features such as topographically controlled fronts and internal waves (Wolanski \& Hamner 1988, Kingsford 1990). This may in turn affect larval availability. Second, finer-scale habitat structures are dependent on the rock base. Sites exposed to wave action are characteristically composed of hard rock, such as greywacke, which often forms complex structures. In contrast, the softer rocks found in more sheltered sites provide less topographic complexity.

Broad-scale patterns were very strong and appeared to hold across sites. Depth, more than presence or absence of macroalgae, appeared to be the main factor characterising the guild structure below $10 \mathrm{~m}$. Some species were found primarily at greater depths (e.g. Notoclinops caerulepunctus, yellow/black triplefin), while other species were found only in shallower water (e.g. N. yaldwyni, Bellapiscis lesleyae). In addition, there was a group of species found at all depths (N. segmentatus, Ruanoho whero, Forsterygion varium). At depths of less than $10 \mathrm{~m}$, the type of macroalgal structure does appear to be important. This is demonstrated in part by the increased relative abundance of the 
blenny Parablennius laticlavius in barren rock habitats and also by a difference in guild structure correlated with wave exposure. $N$. yaldwyni characterised the shallow encrusting algae habitat on exposed shores, whereas F. lapillum characterised the shallow Carpophyllum flexuosum forest in the sheltered sites. The responses of fishes to macroalgal stands have been widely documented (Choat \& Ayling 1987, Bodkin 1988, DeMartini \& Roberts 1990), but fish response to the interaction between depth and macroalgal cover has rarely been explored (but see Jones 1984).

Where I recorded significant numbers of recruits of species, I found that recruits had the same broad-scale habitat distributions as the adults. This suggests that blennioids might exert habitat choice at the broad scale during the settlement period. Kingsford \& Choat (1989) noted that some tripterygiid larvae appear to track the outer edge of the surge zone during rough weather. They hypothesised that this would result in settlement to deeper reefs. They also noted that tripterygiid larvae could remain in the immediate subtidal during both flood and ebb tides, which might lead to settlement in the shallows. Depth-related patterns of settlement of coral reef fishes have also been recorded (e.g. Eckert 1985), though the mechanisms responsible are unclear. Jones (1984) found that juveniles of the labrid Notolabrus (formerly Pseudolabrus) celidotus recruited into Ecklonia radiata forest in the shallows but not in deeper water. Differences in blennioid settlement patterns may be partly explained by speciesspecific behaviour of pre-settlement fish. The behaviour of the larvae of species found in deep water may be different from that of shallow-water species. These fish may be different again from the larvae of fish that recruit into all broad-scale habitats and depths, e.g. Forsterygion varium (Connell \& Jones 1991). The behaviour of fish larvae during settlement is probably complex (Kaufman et al. 1992) and may be worthy of more attention in broad-scale habitat selection studies

Blennioid fish displayed considerable overlap in their use of fine-scale habitats. All species were found in most habitat types. There were, however, 2 general categories of fine-scale habitats which couid be distinguished by the degree of shelter they afforded. Habitats that appeared to provide limited shelter (the tops, sides, and under rock habitats) were occupied by most species - especially Notocinops segmentatus, $N$. yaldwyni and Forsterygion varium. In contrast, highcover cover habitats (overhangs and cracks) were occupied largely by Ruanoho whero.

Some habitat types were occupied only by certain species. The 'top of cobbles' habitat was occupied largely by Forsterygion varium, Ruanoho whero, and $F$. lapillum. In contrast, the 'underneath cobbles' habitat was occupied primarily by $R$. whero. F. lapillum was the main species found on sand a few metres from the reef. Most other species (with the occasional exception of $F$. varium) were not found this far from shelter. Urchins were used as refuges by recruits of Notocinops segmentatus and Parablennius laticlavius, both of which were found in low-shelter habitats. The blenny $P$. laticlavius was the sole occupant of molluscbored holes. This is a habit shared with many other blennies (e.g. Acanthemblaria spp.). Behavioural differences affected the use of habitats at this scale. Newly settled individuals of most species appeared to exercise the same fine-scale habitat preferences as the adults. For example, young post-settlement $N$. segmentatus were found on the same exposed rock faces as the adults, and $R$. whero recruits were associated with cobbles or deep cracks.

Although fine-scale habitat overlap was high, the degree of the association of some species with particular fine-habitat types is in contrast to the high overlap often recorded in tropical systems (see review by Ross 1986). Competitive displacement from fine-scale habitats has been recorded in the tropics (Hixon 1980, Robertson 1984, Jones 1986) and does occur within some tripterygiid species (Thompson 1979) as well as between the tripterygiid Forsterygion varium and the labrid Notolabrus celidotus (Thompson \& Jones 1983). It is possible that competitive displacement might exert an effect on the fine-scale distribution of blennioids and deserves examination at this scale

The effects of microhabitat on recruitment (Shulman 1985b, Roberts \& Ormond 1987, Levin 1991) and postrecruitment (Shulman 1985a, b, Connell \& Jones 1991) processes have been examined. The availability of shelter from predators has been found to be important in altering survivorship patterns of some fish (e.g. Shulman 1985a). Predation has been suggested as an important process in structuring Forsterygion varium populations (Connell \& Jones 1991); predator strikes on blennioids in this study were reasonably common (author's pers. obs.). The relative effect of fine-scale habitat on the final distributions of adults is a topic worthy of more investigation and could be profitably approached using habitat manipulation techniques (e.g. Connell \& Jones 1991).

Despite the importance of organism/habitat relationships in ecological theories, it is clear that habitat association is not a simple parameter to measure. Mechanistically, processes operate at a range of scales. The measurable response of organisms to these processes will be 'filtered' by the scales at which organisms perceive and respond to their environment, and filtered again by the observation scale of the researcher (Allen \& Starr 1982). Consequently, the strength of habitat association is interpretable only in the context of the scales at which it was measured. 
In this study I have identified a number of patterns. The scale at which these patterns become apparent enables the formulation of a future research program. Larvae of most species appear to be available at most sites. Larval availability of the more restricted species could be investigated using plankton sampling methods such as ichthyoplankton tows or light-traps (Doherty 1987). Having established larval availability, it remains to be determined whether sufficient habitat (at broad and fine scales) is available and whether this habitat is present at a scale that pre-settlement fish can perceive and respond to. Experimental manipulation of habitats at this scale may be useful in this respect (author's unpubl. data). Following settlement, the mediation of post-recruitment processes (such as predation and competition) by fine-scale habitat structure should also be experimentally examined. A structured, appropriately scaled research program of this sort should provide a conceptually coherent view of organisation of this assemblage.

While a multi-scale approach may generate new research directions, it is not without its difficulties. Hierarchical spatial scales are not independent, i.e. associations at one scale are likely to influence associations at other scales. Consequently, integration across scales is likely to provide the most important problem to be overcome in a 'science of scale' (Meentemeyer \& Box 1987). In this study, I considered habitat interdependence using an ad hoc procedure. Similar investigations will benefit from a more structured approach, e.g. placing samples to cover as wide a range of different combinations of large/broad/fine-scale habitats as possible to enable the relative influences of processes operating at different scales to be statistically factored out. Increasingly important will be the recognition and measurement of spatial covariation - measured as spatial autocorrelation (Legendre 1993). Spatial position will be an important parameter to include in further investigation. When these difficulties are addressed methodologically and conceptually, scale is likely to become a standard component of most ecological investigations.

Acknowledgements. I thank all those who helped in the field, especially Russell Cole. Brady Doak skippered the RV 'Proteus' to the offshore islands. Comments on various forms of the manuscript were made by Russell Cole, Bob Creese, Geoff Jones, and Richard Taylor. The final manuscript benefitted greatly from the comments of 3 anonymous reviewers. This paper is a contribution from the University of Auckland Leigh Marine Laboratory.

\section{LITERATURE CITED}

Addicott JF, Aho JM, Antolin MF, Padilla DK, Richardson JS, Soluk DA (1987) Ecological neighbourhoods: scaling environmental patterns. Oikos 49:340-346
Alevizon W, Richardson R, Pitts P, Serviss G (1985) Coral zonation and patterns of community structure in Bahamian reef fishes. Bull mar Sci 36:304-318

Allen TFH, Starr TB (1982) Hierarchy: perspectives for ecological complexity. University of Chicago Press, Chicago

Anderson GRV, Ehrlich AH, Ehrlich PR, Roughgarden JD, Russell BC, Talbot FH (1981) The community structure of coral reef fishes. Am Nat 117:476-495

Ayling AM, Grace RV (1971) Cleaning symbiosis among New Zealand fish. NZ J mar Freshwat Res 5:205-218

Bell SS, McCoy ED, Muschinsky HR (1990) Habitat structure: the physical arrangement of objects in space. Chapman \& Hall, London

Bodkin JL (1988) Effects of kelp forest removal on associated fish assemblages in central California. J exp mar Biol Ecol $117: 227-238$

Carr MH (1989) Effects of macroalgal assemblages on the recruitment of temperate zone reef fishes. J exp mar Biol Ecol 126:59-76

Choat JH, Ayling AM (1987) The relationship between habitat structure and fish faunas on New Zealand reefs. $J$ exp mar Biol Ecol 110:257-284

Choat JH, Ayling AM, Schiel DR (1988) Temporal and spatial variation in an island fish fauna. $J$ exp mar Biol Ecol 121:91-111

Choat JH, Schiel DR (1982) Patterns of distribution and abundance of large brown algae and invertebrate herbivores in subtidal regions of northern New Zealand. J exp mar Biol Ecol 60:129-162

Connell SD, Jones GP (1991) The influence of habitat complexity on postrecruitment processes in a temperate reef fish population. J exp mar Biol Ecol 151:271-294

DeMartini EE, Roberts DA (1990) Effects of giant kelp (Macrocystis) on the density and abundance of fishes in a cobblebottom kelp forest. Bull mar Sci 46:287-300

Dennis GD, Bright TJ (1988) Reef fish assemblages on hard banks in the northwestern Gulf of Mexico. Bull mar Sci 43: 280-307

Doherty PJ (1987) Light traps: selective but useful devices for quantifying the distributions and abundances of larval fishes. Bull mar Sci 41:423-431

Doherty PJ, Williams D McB (1988a) Are local populations of coral reef fishes equilibrial assemblages? The empirical database. Proc 6th Int Symp Coral Reefs 1:131-139

Doherty PJ. Williams D McB (1988b) The replenishment of coral reef fish populations. Oceanogr mar Biol A Rev 26 : $487-551$

Ebeling AW, Larson RJ, Alevizon WS (1980a) Habitat groups and island-mainland distribution of kelp-bed fishes off Santa Barbara, California. In: Power DM (ed) Multidisciplinary symposium on the Channel Islands. Santa Barbara Museum of Natural History, Santa Barbara, p 403-429

Ebeling AW, Larson RJ, Alevizon WS, Bray RN (1980b) Annual variability of reef-fish assemblages in kelp forests off Santa Barbara, California. Fish Bull US 78:361-377

Eckert GJ (1985) Settlement of coral reef fishes to different natural substrata and at different depths. Proc 5th Int Coral Reefs Congr, p 385-390

Francis MP, Brook FJ, Randall JE, Cole R, Williams MW, Ward C) Davis M (1990) Norfolk Island fish survey: 11-26 November 1989. Unpubl report to Australian National Parks and Wildlife Service

Gladfelter WB, Gladfelter EH (1978) Fish community structure as a function of habitat structure on West Indian patch reefs. Rev Biol Trop Suppl 1:65-84

Gladfelter WB, Ogden JC, Gladfelter EH (1980) Similarity and diversity among coral reef fish communities: a com- 
parison between tropical western Atlantic (Virgin Islands) and tropical central Pacific (Marshall Islands) patch reefs Ecology 61:1156-1168

Gorham JC, Alevizon WS (1989) Habitat complexity and the abundance of juvenile fishes residing on small scale artificial reefs. Bull mar Sci 44:662-665

Greenacre MJ (1984) Theory and applications of Correspondence Analysis. Academic Press, New York

Greenfield DW, Johnson RK (1990a) Community structure of western Caribbean blennioid fishes. Copeia 1990: $433-448$

Greenfield DW, Johnson RK (1990b) Heterogeneity in habitat choice in cardinalfish community structure. Copeia 1990: $1107-1114$

Hardy GS (1989a) The 'blue-dot' triplefin; a new species of Notoclinops Whitley, 1930 (Pisces: Tripterygiidae) from New Zealand. J Royal Soc NZ 19:327-332

Hardy GS (1989b) The genus Forsterygion Whitley \& Phillipps, 1939 (Pisces: Tripterygiidae) in New Zealand and Australia, with descriptions of two new species. $J$ nat Hist 23:491-512

Hixon MA (1980) Competitive interactions between California reef fishes of the genus Embiotoca. Ecology 61: 918-931

Holbrook SJ, Carr MH, Schmitt RJ, Coyer JA (1990a) Effect of giant kelp on local abundance of reef fishes: the importance of ontogenetic resource requirements. Bull mar Sci 47:104-114

Holbrook SJ, Schmitt RJ, Ambrose RF (1990b) Biogenic habitat structure and characteristics of temperate reef fish assemblages. Aust J Ecol 15:489-503

Jackson DA, Harvey HH (1989) Biogeographic associations in fish. assemblages: local vs regional processes. Ecology 70 $1472-1484$

Jones GP (1984) Population ecology of the temperate reef fish Pseudolabrus celidotus Bloch \& Schnejder (Pisces: Labridae). I. Factors influencing recruitment. J exp mar Biol Ecol 75:257-276

Jones GP (1986) Food availability affects growth in a coral reef fish. Oecologia 70:136-139

Jones GP (1988) Ecology of rocky reef fish of north-eastern New Zealand: a review. NZ $J$ mar Freshwat Res 22: $445-462$

Kaufman L, Ebersole J, Beets J, Mclvor CC (1992) A key phase in the recruitment dynamics of coral reef fishes: post-settlement transition. Environ Biol Fish 34:109-118

Kingsford MJ (1989) Distribution patterns of planktivorous reef fish along the coast of northeastern New Zealand Mar Ecol Prog Ser 54:13-24

Kingsford MJ (1990) Linear oceanographic features: a focus for research on recruitment processes. Aust $J$ Ecol 15 $391-401$

Kingsford MJ, Choat $\mathrm{JH}$ (1989) Horizontal distribution patterns of presettlement reef fish: are they influenced by the proximity of reefs? Mar Biol 101:285-297

Kotliar NB, Wiens JA (1990) Multiple scales of patchiness and patch structure: a hierarchical framework for the study of heterogeneity. Oikos 59:253-260

Legendre P (1993) Spatial autocorrelation: trouble or new paradigm? Ecology 74:1659-1673

Leum LL, Choat JH (1980) Density and distribution patterns of the temperate marine fish Cheilodactylus spectabilis (Cheilodactylıdae) in a reef environment. Mar Biol 57: $327-337$

Levin PS (1991) Effects of microhabitat on recruitment variation in a Gulf of Maine reef fish. Mar Ecol Prog Ser 75: $183-189$
Luckhurst BE, Luckhurst K (1978a) Analysis of the influence of substrate variables on coral reef fish communities. Mar Biol 49:317-323

Luckhurst BE, Luckhurst K (1978b) Diurnal space utilization in coral reef fish communities. Mar Biol 49:325-332

Meentemeyer V, Box EO (1987) Scale effects in landscape studies. In: Turner MG (ed) Landscape heterogeneity and disturbance. Ecol Studies 64, Springer-Verlag, New York, p 15-34

Ogden JC, Ebersole JP (1981) Scale and community structure of coral reef fishes: a long term study of a large artificial reef. Mar Ecol Prog Ser 4:97-103

Paulin CD, Stewart A, Roberts C, McMillan P (1989) New Zealand fish: a complete guide. Natl Mus NZ Misc Ser No 19

Risk MJ (1972) Fish diversity on a coral reef in the Virgin Islands. Atoll Res Bull 153:1-6

Roberts CM, Ormond RFG (1987) Habitat complexity and coral reef fish diversity and abundance on Red Sea fringing reefs. Mar Ecol Prog Ser 41:1-8

Robertson DR (1984) Cohabitation of competing territorial damselfishes on a Caribbean coral reef. Ecology 65: $1121-1135$

Root RB (1967) The niche exploitation pattern of the blue-gray gnatcatcher. Ecol Monogr 37:317-350

Ross ST (1986) Resource partitioning in fish assemblages: a review of reef studies. Copeia 1986:352-388

Russ G (1984) Distribution and abundance of herbivorous grazing fishes in the central Great Barrier Reef. I. Levels of variability across the entire continental shelf. Mar Ecol Prog Ser 20:23-34

Sale PF (1975) Patterns of use of space in a guild of territorial reef fishes. Mar Biol 29:89-97

Sale PF (1977) Maintenance of high diversity in coral reef fish communities. Am Nat 111:337-359

SAS Institute (1987) SAS/STAT'M guide for personal computers, Version 6 edn. SAS Institute, Inc, Cary, NC

SAS Institute (1988) SAS technical report P-179. Additional SAS/STATrM procedures, Release 6.03. SAS Institute, Inc, Cary, NC

Schmitt RJ, Holbrook SJ (1985) Patch selection by juvenile black surfperch (Embiotocidae) under variable risk: interactive effects of food quality and structural complexity. $J$ exp mar Biol Ecol 85:269-285

Schmitt RJ, Holbrook SJ (1990a) Contrasting effects of giant kelp on dynamics of surfperch populations. Oecologia 84:419-429

Schmitt RJ, Holbrook SJ (1990b) Population responses of surfperch released from competition. Ecology 71:1653-1665

Shulman MJ (1985a) Recruitment of coral reef fishes: effects of distribution of predators and shelter. Ecology 66: $1056-1066$

Shulman MJ (1985b) Variability in recruitment of coral reef fishes. J exp mar Biol Ecol 89:205-219

Smith CL, Tyler JC (1972) Space resource sharing in a coral reef fish community. Bull Nat Hist Mus Los Angeles County 14:125-170

Thompson S (1979) Ecological and behavioural factors influencing the distribution and abundance patterns of tripterygiid fishes with particular reference to Tripterygion varium. MSc thesis, University of Auckland

Thompson S (1983) Homing in a territorial reef fish. Copeia 1983:832-834

Thompson SM, Jones GP (1983) Interspecific territoriality and competition for food between the reef fishes Forsterygion varium and Pseudolabrus celidotus. Mar Biol $76: 95-104$ 
Tonn WM, Magnuson JJ, Rask M, Toivonen J (1990) Intercontinental comparison of small-lake fish assemblages: the balance between local and regional processes. Am Nat $136: 345-375$

Wiens JA (1989) Spatial scaling in ecology. Funct Ecol 3: $385-397$

This article was presented by D. M. Alongi (Senior Editorial Advisor), Townsville, Australia
Williams D McB (1982) Patterns in the distribution of fish communities across the central Great Barrier Reef. Coral Reefs $1: 35-43$

Wolanski E, Hamner WM (1988) Topographically controlled fronts in the ocean and their biological significance. Science $241: 177-181$

Manuscript first received: October 11, 1994

Revised version accepted: February 28, 1995 